University of Wollongong

Research Online

Faculty of Social Sciences - Papers (Archive) Faculty of Arts, Social Sciences \& Humanities

2013

Shepherds in the gym: employing a pastoral power analytic on caring teaching in HPE

Louise McCuaig

University of Queensland

Marie Ohman

Orebro University

Jan Wright

University of Wollongong, jwright@uow.edu.au

Follow this and additional works at: https://ro.uow.edu.au/sspapers

Part of the Education Commons, and the Social and Behavioral Sciences Commons

Research Online is the open access institutional repository for the University of Wollongong. For further information contact the UOW Library: research-pubs@uow.edu.au 


\title{
Shepherds in the gym: employing a pastoral power analytic on caring teaching in HPE
}

\begin{abstract}
Drawing on research conducted in Australian Health' and Physical Education (HPE) and Swedish Physical Education and Health (PEH), this paper demonstrates the analytic possibilities of Foucault's notion of pastoral power to reveal the moral and ethical work conducted by HPE/PEH teachers in producing healthy active citizens. We use the pastoral power analytic to make visible the consequences of caring HPE/PEH teaching practices which appear unassailable as producing a general 'good' for all students. In so doing we undertake the challenge posed by Nealon to be attuned to those social practices that appear beyond reproach as 'power becomes more effective while offering less obvious potential for resistance'. From this Foucauldian perspective we argue that caring HPE/PEH teachers employ a wide range of normalization tools to interpellate young people into a specific model of 'normal' healthy living, simultaneously determining those who represent problematic deviations from the norm. We further argue that instead of discarding or ignoring these students, such deviations call upon the HPE/PEH teacher to care more fervently, to employ more intense strategies of individualization such as togetherness, encouragement and familiarity. In conclusion, we highlight the tensions and implications that may result for HPE/PEH teachers and their students.
\end{abstract}

\section{Keywords}

employing, gym, shepherds, pastoral, power, hpe, analytic, caring, teaching

\section{Disciplines}

Education | Social and Behavioral Sciences

\section{Publication Details}

McCuaig, L., Ohman, M. \& Wright, J. (2013). Shepherds in the gym: employing a pastoral power analytic on caring teaching in HPE. Sport, Education and Society, 18 (6), 788-806. 
Shepherds in the Gym: Employing a pastoral power analytic on caring teaching in HPE

\section{Dr Louise McCuaig}

School of Human Movement Studies

The University of Queensland

Queensland, Australia

lmc@hms.uq.edu.au

Corresponding Author

\section{Dr Marie Öhman}

Department of Health Sciences

Örebro University

Örebro, Sweden

marie.ohman@hi.oru.se

\section{Professor Jan Wright}

Faculty of Education

University of Wollongong

Wollongong, Australia

jwright@uow.edu.au 


\begin{abstract}
Drawing on research conducted in Australian Health and Physical Education (HPE) and Swedish Physical Education and Health (PEH), this paper demonstrates the analytic possibilities of Foucault's notion of pastoral power to reveal the moral and ethical work conducted by HPE/PEH teachers in producing healthy active citizens. We use the pastoral power analytic to make visible the consequences of caring $\mathrm{HPE} / \mathrm{PEH}$ teaching practices which appear unassailable as producing a general "good” for all students. In so doing we undertake the challenge posed by Nealon (2008) to be attuned to those social practices that appear beyond reproach as 'power becomes more effective while offering less obvious potential for resistance' (p. 71). From this Foucauldian perspective we argue that caring HPE/PEH teachers employ a wide range of normalization tools to interpellate young people into a specific model of "normal” healthy living, simultaneously determining those who represent problematic deviations from the norm. We further argue that instead of discarding or ignoring these students, such deviations call upon the HPE/PEH teacher to care more fervently, to employ more intense strategies of individualization such as togetherness, encouragement and familiarity. In conclusion, we highlight the tensions and implications that may result for HPE/PEH teachers and their students.
\end{abstract}

\title{
Keywords
}

Health and physical education, caring teaching, pastoral power, normalization, Foucault 


\section{Shepherds in the Gym: Employing a pastoral power analytic on caring teaching in HPE/PEH}

\section{Introduction}

Drawing on research conducted in Australian Health and Physical Education (HPE) and Swedish Physical Education and Health (PEH), this paper demonstrates the analytic possibilities of Foucault's notion of pastoral power to reveal the moral and ethical work conducted by HPE/PEH teachers in producing healthy active citizens. We use the pastoral power analytic to make visible the consequences of caring HPE/PEH teaching practices which appear unassailable as producing a general 'good' for all students. In so doing we undertake the challenge posed by Nealon (2008) to be attuned to those social practices that appear beyond reproach as 'power becomes more effective while offering less obvious potential for resistance' (p. 71). From this Foucauldian perspective we argue that caring HPE/PEH teachers employ a wide range of normalization tools to interpellate young people into a specific model of "normal” healthy living, simultaneously determining those who represent problematic deviations from the norm. We further argue that instead of discarding or ignoring these students, such deviations call upon the HPE/PEH teacher to care more fervently, to employ more intense strategies of individualization such as togetherness, encouragement and familiarity. In conclusion, we highlight the tensions and implications that may result for HPE/PEH teachers and their students.

In presenting this argument we focus on two research studies conducted in Australia and Sweden, the more substantial findings of which have been presented elsewhere (McCuaig, 2011; McCuaig \& Tinning, 2010; Öhman, 2010). The Australian research comprised of a genealogical project which traced the emergence and transformation of ethical practices concerning pleasurable bodies within the apparatus of modern schooling. More specifically this research 
focused on three Queensland HPE curriculum reform projects and the programs of teacher education surrounding the design and implementation of each new syllabus. For this paper, we draw on these findings to reveal the principles and practices that have been employed in governmental programs designed to incite Australian HPE teachers to constitute themselves as agents of pastoral power. The empirical material of the second study comprises 15 video recorded lessons from five Swedish schools, which were collected in connection with a national evaluation of Physical Education (PE) in Swedish compulsory, upper secondary schools. Lesson transcripts from this study have been analyzed for this paper, employing a pastoral power lens to demonstrate how the teachers' interactions with their students interpellate the students as healthy active citizens through specific technologies of pastoral power.

Before we begin, it is important to state that this paper does not adopt a comparative stance. We do not aim to compare Australian HPE with Swedish PEH or present the Swedish data as evidence for the uptake of discourses identified within the Australian context. Such an approach would efface the sociohistorical, political and cultural nuances at play within each context. Instead we draw upon the Australian findings to provide an initial engagement with strategies that have sought to mobilize HPE teachers as agents of pastoral power. Against this understanding, we move on to the lived experiences and practices of Swedish PEH teachers to provide insight into the employment of pastoral power technologies within HPE/PEH classrooms. In the final discussion we employ Foucault and others' commentary on pastoral power, care and normalization to highlight the tensions, contradictions and implications that may result from our enthusiasm as a profession to embrace caring teaching.

\section{HPE/PEH, care and caring teaching}


As McCuaig (2011) demonstrates elsewhere, the HPE/PEH profession has undertaken an increasing advocacy for caring teacher-student relationships (see also Owens \& Ennis, 2005; Larson \& Silverman, 2005; Rovegno \& Kirk, 1995). For Armour and Jones (1998), the importance of care to PE teachers is 'inextricably linked to the ideal of using physical education, and particularly sport, as a form of social and moral education' (p. 108). Many commentators draw attention to the capacity for PE teachers to shift student-teacher dynamics from the 'impersonal, vertical, highly regulated relationship of teacher and student toward a more personal, horizontal relationship in which there is an exchange of equals’ (Brown \& Evans, 2004, p. 55). This shift in dynamics potentially allows for 'meaningful and caring relations between students and staff to be established’ (Armour \& Jones, 1998, p. 120), which the HPE/PEH profession has long argued, provides its teachers with the foundations upon which they can undertake the social and moral shaping of future citizens (McCuaig, 2011).

Nonetheless, it is surprising to discover that Armour and Jones (1998) believe 'the social/moral knowledge claims for physical education have failed' (p. 17). Indeed, these researchers conclude that their PE teachers' 'aspirations were not exceptional and could be matched by other teachers in various ways in their own subjects.' (p. 113). Here they argue that to be qualitatively different, HPE 'caring would need to be demonstrated at a deeper individualistic level' (Armour \& Jones, 1998, p. 113), reflective of Noddings’ $(1984,1992)$ stringent criteria of caring teaching. Instead, Armour and Jones argued that moral education claims were being used as strategic rhetoric to hide the aspects of PE teaching their participants really cared about, that is 'the measurable improvements in pupil’s physical aptitude' (p. 122). The remaining sections of this paper draw on the Foucauldian 'tool-box' (Foucault, 1974, p. 523) to explore and trouble this situation further. Before we present this work, we begin with a brief overview of Foucault's pastoral 
power analytic to establish the characteristic features of this power modality and its mobilization within mass schooling.

\section{Pastoral power and the governance of apprentice citizens through schooling}

Although seemingly disparate, Foucault's genealogies of the modern state and the subject endeavour to 'analyse the connections between what he called technologies of the self and technologies of domination, the constitution of the subject and the formation of the state' (Lemke, 2000, p. 2). Acknowledging political power's evolution towards a more centralized form, Foucault (1994a) nevertheless proposes an additional transformation of power relationships within late modern societies. Here Foucault (1994a) meticulously outlines the strategies by which the 'modern Western state has integrated into a new political shape an old power technique that originated in Christian institutions.' (p. 332). Foucault labels this power technique, pastoral power.

According to Foucault (1994a), the "strange game" of Christian pastorship designates a very special form of power which is salvation-oriented, oblative, individualizing, coextensive and continuous with life. Foucault (1994a) argues that pastoral power underwent a number of mutations as it spread from religious contexts into the wider, and increasingly secular, social body. First, the objective was no longer leading people to salvation in the next world but in this world, where salvation becomes the acquisition of "worldly" rewards such as health, wellbeing, security and protection. Here the objectives of pastoral power intersect with Foucault's notion of biopower. Biopower refers to the 'knowledge and strategies of power that aim at governing a population's life forces' (Nadesan, 2008, p. 8), and is reflected in 'the techniques, technologies, experts and apparatuses for the care and administration of the life of each and all' (Rose, 2001, p. 
1). As the religious pastorate became a secular political pastorate, public and private institutions such as the school and family provided a host of new pastoral officials and experts, who were charged with "shepherding" the population's health and happiness as a means of securing state wealth and security (Rose, 2001; Nadesan, 2008).

For Foucault (1994a), 'this form of power cannot be exercised without knowing the inside of people's minds, without exploring their souls, without making them reveal their innermost secrets. It implies a knowledge of the conscience and an ability to direct it' (p. 333). According to McNay (1994), Foucault's understanding of the constitution of subjectivity through pastoral technologies involves a 'process of subjection either to an external party or in the form of an internalization of social norms' (p. 123). As such, modern institutions have devised "confessional” strategies to extract information from subjects which is subsequently 'recodified into the discourses of [for example] medicine, psychiatry' (McNay, 1994, p. 122).

Employing Foucault's pastoral power analytic, Hunter (1994) suggests that the emergence of popular schooling serves as an exemplary case of the 'state caring for its citizens as a means of looking after itself' (p. 62). In his genealogical study, Hunter (1994) illustrates the manner in which Christian pastoral pedagogies provided state bureaucrats with the strategies of ethical constitution through which individuals could acquire the capacity to 'attend to their own conduct and make themselves responsible for it' (p. 73). Hunter's work identifies the significance of a new architecture for schooling projects that sought the moral training of the proletariat, most specifically the playground, which provided an arena where students' 'true character and dispositions are exhibited' (p. xiii). Nonetheless, these specially crafted learning environments could not operate to their fullest potential without their partner governmental technology, the caring pastoral teacher. 
Authorities came to believe that teachers engaged in schooling as moral intervention and training would need to be pastoral rather than disciplinary, incorporating the sympathetic demeanours of the spiritual guide and the caring parent, demonstrating a balance of warmth and surveillance, love and discipline. As Hunter (1994) argues, the caring pastoral teacher was required to mediate the shift in schooling practice from coercion to conscience, shaping and transforming raw individuals into the self-governing subjects commensurate with modern citizenship. At his most provocative, Hunter contends that it is 'Christianity’s shepherd-flock game-with its distinctive articulation of surveillance and self-examination, obedience and self-regulation — that continues to provide the core moral technology of the school' (p. xxi). In this paper we present the argument that HPE, with its mandate to produce healthy, active citizens, demonstrates the ongoing significance of the caring pastoral teacher within the contemporary apparatus of mass schooling.

\section{Case Study 1: Constituting the Australian caring pastoral teacher}

In this first case study we present a summary of findings that resulted from a genealogy of subjectification project which explored the strategies, technologies, principles and practices of self-constitution deployed within Australian HPE programs. Genealogies of subjectification pay attention to the similar principles and practices of selfhood adopted across a somewhat coherent group of subjects, who conduct themselves as particular persons, for example, as sportsperson, healthy citizen or teacher (Rose, 2000). According to Rose (2000), the genealogy of subjectification perspective employs an analytic lens upon practices and principles found at the intersection between strategies for the conduct of others and self-constitution, and owes much of its theoretical grounding to Foucauldian ethics. Foucualdian ethics is divided into four major aspects: the ethical substance (what part of the self should be addressed?), the mode of subjection 
(why should selves engage in this work?), forms of elaboration (what tools are available for this ethical work?) and the telos (what is the aim of this ethical work?) (Foucault, 1994b). This "ethical fourfold" provides a tool with which Foucault and others have interrogated contemporary practices of self-constitution. As Rose (2000) explains, these studies explore the 'ways in which individuals experience, understand, judge and conduct themselves' (p. 317) according to an 'authority of some system of truth and of some authoritative individual' (p. 317).

The focus of this Australian study was the constitution of active healthy citizens through twentieth century programs of Australian HPE. Such a study necessitated a parallel exploration of a primary governmental technology mobilized within these programs, namely the HPE teacher. As such, this second project surveyed the strategies by which individuals have been incited to engage in particular regimes of training, adopting specific technologies to shape and conduct themselves as "good" HPE teachers. As Foucault (1990) instructs, such studies are grounded in an exploration of 'texts written for the purpose of offering rules, opinions, and advice on how to behave as one should' (p. 12). This genealogical research consequently focused on the design and implementation of three Queensland HPE syllabus documents in 1952, 1972 and 1999 as each syllabus provides the specific technologies and strategies of training informing the ethical constitution of healthy citizenship. In relation to the good HPE teacher, data upon which the analytic lens was employed included: government reports; research journals of significance to the HPE profession and Queensland education sectors; professional development materials; tertiary education course guides and teacher education curricula; school magazines and promotional material; and, HPE teacher education research and texts.

Findings from this project revealed authorities’ resilient emphasis on a collection of ethical practices that HPE teachers have been incited to adopt in order to construct pastoral relationships 
with their students (McCuaig, 2011). These ethical practices cluster around three broad themes, with the first of these being the expectation that HPE teachers will cultivate a "special” knowledge about and of their students. HPE experts and authorities of the twentieth century have continuously implored teachers to gain a mastery of knowledge about students, availing themselves of the latest biophysical, psychological and sociological research and knowledge (McCuaig, 2008). However, across some seventy years of HPE, commentators have also urged teachers to recognize that such knowledge is useless unless it is considered in light of a teacher's intimate knowledge of her students (DEQ, 1952; QSCC, 1999a). For example, as recent studentcentred approaches privilege the knowledge, skills, needs and capacities of students, teachers have been incited to acquire a comprehensive understanding of these dimensions according to each student's family background, ethnicity, ability, gender, health, personal development and socioeconomic status (QSCC, 1999b; QSCC, 1999c).

Secondly, in seeking to enhance pastoral officials’ access to the consciences of the citizenry, health and education authorities have devised and constructed purpose built environments that incite patients, clients and students to reveal their inner selves (Foucault, 1994a, 1994b; Hunter, 1994, Meredyth \& Tyler, 1993). Similarly, twentieth century HPE literature is replete with information regarding the construction of learning environments that elevate the probability of student revelations and the close teacher-student relationships which enhance the expression of such revelations. An early Queensland Department of Public Instruction (QDPI) annual report clearly articulates this intent, stating that 'to know a boy thoroughly it is necessary to be with him in his games, for the average child is more natural out of doors than when under the restraint of discipline in schools' (QDPI, 1928, p. 44). 
Indeed, a central feature of twentieth century HPE curricula is the conviction that competitive play in sports provides a pre-eminent stimulus for training in the arts of healthy citizenship. For education experts and authorities, the heat of competition is thought to motivate students to reveal their ability to control emotions, respect their opponents, abide by rules, act fairly and try wholeheartedly in the face of challenging circumstances (DEQ, 1952; QSCC, 1999a). In this manner, game play environments have been deployed as mechanisms that provoke young people into revealing their inner selves, whilst simultaneously training them in the practices that monitor and discipline their behaviour according to prevailing standards of good conduct. In current HPE curricula, pedagogical approaches such as Teaching Games for Understanding and Sport Education are advocated as the ideal vehicles through which effective decision making skills by students can be promoted. These skills not only enhance sport and game playing abilities, but prepare students for the complexity and rigours of contemporary living (McCuaig, 2008).

Within the context of these learning environments, HPE teachers are routinely incited to act as unobtrusive guides (DEQ, 1952), or in later syllabus documents, facilitators of learning (QSCC, 1999a). This expectation reflects one of the critical conditions underpinning the success or otherwise of pastoral power practices, namely the capacity of pastoral officials to act as sympathetic guides. From the earliest curriculum materials, teachers are informed that 'it is the teacher's business to act unobtrusively, occasionally to guide, to correct, and to suggest’ (QDPI, 1952, p. 4). In HPE literature of the seventies, the teacher of health education is encouraged to function as an 'an enabler, one who seeks to provide an accepting and facilitating social climate offering ways by which people are encouraged to think their problems through and make decisions' (Carr, 1975, p. 215). This notion of teacher as facilitator is also a critical component of recent HPE syllabus documents in which teachers are encouraged to move to the periphery of 
learning environments to monitor their students' progress, assisting them through an unfolding inquiry with timely questions, feedback and collaborative decision-making (QSCC, 1999c).

Finally, in order to obtain the level of trust that will inspire students to reveal their feelings and thoughts, teachers of HPE are urged to provide exemplary models of good practice in the arts of healthy living, a model that incorporates the very shape, composition and behaviour of their own bodies. In earlier syllabus documents, teachers of PE were informed that the performance and stance of their body provided pupils with a living exemplar of the standard to which they must aspire (Great Britain Board of Education, 1933). Teachers of this early era were also informed that the personality, dispositions and conduct of teachers are paramount, for it is their displays of enthusiasm, vitality and interest in student achievement that 'evokes an alert, active and keen response in the children' (DEQ, 1952, p. 12). Although HPE syllabus materials of the late 1990s do not explicitly articulate the characteristic features of an active, healthy HPE teacher, researchers have demonstrated the popular belief that HPE teachers should be 'the embodiment and custodians of the symbolic qualities of the sporting body and healthy body' (Macdonald \& Kirk, 1996, p. 73). In short, there is a widespread conviction that teachers of HPE cannot be effective in shaping their students' progress in the arts of active, healthy living if their bodies and lifestyles do not provide living exemplars of the benefits and rewards of such work.

Teachers who have a responsibility to deliver programs of HPE have thus comprised one of the pre-eminent groups (families being the other) that have been afforded a sustained and legitimate opportunity to train and shape individuals' progress in the arts of good citizenship. Drawing on social theory, researchers have argued that contemporary citizenship privileges the health conscious, self-monitoring, rational subject, who is agentic in the face of risk and responsible for her own health and destiny (Wright \& Harwood, 2009). Indeed, Australian researchers have 
revealed the inherent tensions within current HPE syllabus documents whose rationales advocate socially liberal policies whilst program outcomes privilege the neo-liberal discourses of individual achievement, valorized middle-class values and expectations of personal responsibility (Rossi, Tinning, McCuaig, Sirna \& Hunter, 2009). With its emphasis on obligations, responsibilities and advocacy this model of healthy living appears both ambitious and onerous, leaving little insight into the mechanisms by which young peoples' engagement might be incited or mobilized (McCuaig, 2008).

As these findings have presented an overview of the intended constitution of caring pastoral teachers as expressed in the Australian HPE literature, this work does not address the lived experiences and practices of caring HPE/PEH teachers. For further insight into the employment of pastoral power technologies within HPE/PEH classrooms, we now turn to our second case study.

\section{Case Study Two: Caring teaching in Swedish PE lessons}

Until recently, Swedish policy and curriculum documents have not explicitly articulated the pastoral responsibilities of PEH teachers. However, in recent education policy contexts the remit of Swedish schooling's role in the creation of responsible citizens has become more explicit (Annerstedt, 1991; Quennerstedt, Burrows \& Maivorsdotter, 2010). In comparison with earlier documents, current PE curricula emphasise student participation in, and responsibility for, decision-making, setting personal goals and problem-solving (The National Swedish Agency for Education [NSAE], 2000b). For example, one official state report argues that 'Citizens must be given autonomy so that everyone is able to both independently and collectively take charge of their own lives. The public exercise of power must not strip citizens of this desire to have control 
over and take responsibility for their lives’ (SOR, 2000, p. 120). As with the Australian context, the role of the teacher consequently becomes that of a facilitator of learning, one who is in charge of setting up environments that best facilitate the achievement of these goals. Although the Swedish curriculum does not provide guidelines and instructions for teachers’ pedagogical work or state anything specifically about the role of the teacher, in a recent report on sustainable teacher education (SOR, 2008), concepts like care and relationships were central. Here, education is essentially regarded as a question of encounters between people and as such, teachers are exhorted to develop warm and close relationships with their students. A good relationship is considered important for the child's development, although the report notes that an excessive reliance on the teacher impedes the development of students' independence (SOR, 2008).

Participation and responsibility are also concepts that are expressed in the most recent Swedish PEH syllabus. According to the syllabus, the aim of PEH is to develop students' physical, mental and social capacities and the acquisition of skills that will enable Swedish youth to adopt healthy lifestyles (NSAE, 2000b). Among other things, the subject is designed to improve students’ knowledge of health issues and how personal lifestyles can affect health. Through their experience of PEH students are expected to learn how to take responsibility for their health, and be able to consider, choose and evaluate movement and physical activity from a broad health perspective. Further, the subject is expected to stimulate the capacity for and enjoyment of movement and to encourage responsibility for one's own physical exercise (NSAE, 2000c).

Given this background, in this section we draw on data from a Swedish study where a total of 15 PEH lessons from Years 2 to 9 were video recorded. The study’s empirical material has a rich geographic spread as it includes schools from large cities, medium-sized towns and rural areas 
across Sweden. Twelve teachers - four women and eight men - of varying ages took part in the study. We use this data to demonstrate how the teachers' caring interactions with their students interpellate them as healthy active citizens through specific technologies of pastoral power. We also demonstrate how the students interpolate themselves into the discourse or resist such positioning.

\section{Togetherness and caring}

In many of the lessons, teachers engaged in practices which served to build a sense of togetherness, caring and equality through language which suggests a shared relationship and experiences. We argue that these practices served as technologies of inclusion/exclusion, whereby a sense of 'us' is constituted which at the same time excludes those who do not join in the shared experience. Although exclusion is the more commonly identified technique of power, practices of inclusion work subtly to exclude those who do not share common goals, values or projects (Gore, 1998). In the lessons, this occurs through a device common in physical education lessons - the use of the pronoun 'we' to indicate a collective class project (see also Wright, 1997). The pronoun "we" is often used in the beginning of the lessons, when information is given to students regarding what should be done during the lesson:

I would just like to tell you what we will be doing today. We will warm up by playing "dip ball”, do a bit of weight training and then finish off with a ball game. (Lesson 15)

As teachers employ the term of “we” - “today we're going to workout” (lesson 3) - power is not enacted in the sense of someone being ordered to act. Instead, this action serves to reduce the distance between students and teachers; a governing technique which focuses on the fact that we all share and are involved in a common project. That the project is intended to be a shared 
experience is obvious in another lesson where students are doing press-ups and the teacher asks them whether their arms ache (lesson 7). One student responds by saying: "Not at all”, to which the teacher replies: “Then we'll do it again!”. The teacher, however, does not join in to do the press-ups: the "we" joins the teacher with the rest of the class as a collective, who should share in the teacher's enthusiasm to complete the task. This practice excludes as it includes. Those students who do not join in both visibly (by sitting on the side) or with less enthusiasm than that evinced by the teacher are through this use of language defined as “outsiders”.

This spirit of togetherness is evident in all the video recorded lessons. The success of this pastoral power technique is twofold. In constructing a learning environment of togetherness, caring and equality, even the most recalcitrant of students can be motivated to reveal their fears, feelings or physical capacities. In other words, these caring teaching practices facilitate the PE teacher's access to the 'consciences' of their young charges. Secondly, these dynamics establish a relation between what ought to be done and the idea that you yourself want to do it. These pastoral techniques support students' progress towards self-governance and the internalisation of the practices of self-surveillance and self-problematization.

\section{Encouraging and inspiring}

The process of inclusion/exclusion is further evident in the way that the teachers set standards for student participation and in so doing engage in normalizing practices. In the examples provided below, the teachers set desired standards of participation through encouragement and praise of certain action patterns. In this sense encouragement can be regarded as a governing technique as this reinforcement of specific actions or attitudes serves to confirm for all students the correct and desired actions. In the lessons, teachers often used frequent and enthusiastic reinforcements 
like "well done", "excellent” and "you are very talented", especially in situations where students are active and demonstrate correct intent. For example, in one lesson, Year 7 girls moved into a room where fitness and body-building exercises were to be executed. All the students set to work, albeit with varying intensity, and the teacher went around the room giving encouragement:

Give it all you've got, well done, you are very talented.

At the end of the lesson the teacher praised the students as follows:

You've all worked very hard. It's at times like this that I know why being a teacher is so enjoyable. I'm very proud of you. A round of applause for everyone. (Lesson 2)

In this example praise is directed at the entire group through the teacher's “you've all worked very hard” and "a round of applause for everyone”. Such a comment again includes 'all' the students as having worked hard and worthy of praise. According to the video evidence some students worked very intensively, whilst others less so. The teacher nonetheless constitutes them all as good subjects, praise and encouragement has not been specifically directed at those students who demonstrated the best style or skill. Instead many of the teacher's comments refer to the spirit accompanying the performance of each action, rather than the provision of feedback on what might constitute correct performance. Such commentary indicates that the criterion for praise is a willingness to work hard and a "do my best" attitude, and at the conclusion of the lesson everybody is perceived as having the right attitude and therefore everybody is to be rewarded. This governing technique indicates to students those actions and attitudes that are valued and that those who enact these desirable actions and attitudes are "good" students.

Moreover, expressions such as "I am very proud of you" and "being a teacher is so enjoyable" create familial-like relationships of caring. "I am very proud of you" is easily associated with the 
affirmation that a parent provides to a child. Such statements create a particular learning environment in which students are invited to be cared for. To refuse such an invitation, to refuse to be included, takes considerable agency; it defines one as "not-normal", for what kind of person would not desire such a caring relationship.

In another lesson, normalization works through defining what is undesirable and associating this with feelings of shame (Rose, 1999). There is considerable affective value in doing what is right and being acknowledged as a good person in the eyes of the teacher and possibly the class. There is also the affective loading of what happens if you don't do this - what is at risk - being a bad person and most importantly, disappointing the teacher. In this lesson students carry out the prescribed exercises at different stations, albeit with differing degrees of intensity. At the end of the lesson the teacher says:

It demands a lot of you. Did any of you feel you'd been slacking? Has everybody worked hard? (Lesson 1)

The students neither respond to the questions posed nor indicate any intention of responding. On closer inspection it is obvious that the teacher is not expecting any responses: she doesn't look around, repeat the question or show any sign of anticipation. This suggests that the teacher asks her rhetorical questions to remind the students of their responsibility to work hard without slacking. "Did any of you feel...?”, appeals to the individual's own assessment of his or her actions.. Here, allowing the students themselves to recognise how they relate to the desired objective appears important. Am I a person who slacks, one to whom shame is attached, or a person who works hard? Appealing to the students' own assessment of their actions in relation to the established norm of hard work facilitates their uptake of the self-surveillance and self- 
problematization tools underpinning self-governance. Thus, the students are not expected to admit their successes or failures to the teacher, but to themselves in relation to the norms and values regarded as good and right in the context of the activity. Reflecting on one's actions and oneself in relation to normality (the right attitude to physical activity) demonstrates the staged guidance the teacher provides to the class and each student as they undertake their journey towards self-governance.

Encouragement and the teachers' creation of familiarity thereby serve to guide the correct way of action and illustrates the theme of pastoral power in action. As Hunter's (1994) work has demonstrated the employment of a demeanour associated with the caring parent is by no means a unique feature of HPE/PEH, as this power technique builds towards a self-governance that enables students to adopt the habit of acting and thinking in ways commensurate with good citizenship. Nevertheless, as will become more evident in the examples to follow, these pastoral techniques become increasingly potent as they are mobilised within HPE/PEH's efforts to train "pleasurable bodies".

\section{Pleasurable experiences}

In many of the lessons, the teachers explicitly made associations between practices and (mostly positive) affect or emotions, that is they specifically associate engaging in physical activity, particularly vigorous physical activity, with fun and pleasure. They often asked questions that focus on the fun aspect: “Have you had fun today?” “Was it fun?” “That was fun wasn’t it?” The following examples illustrate the creation of this relationship between physical exertion and fun. In the first lesson students performed a number of exercises at various stations: press-ups, situps, hula-hooping, skipping, moving bean bags between cones, climbing over bars and running 
up and down on a bench. Towards the end of the lesson the teacher and students gathered together in a circle on the floor.

Teacher: How did it feel? Was it fun?

Student: Good.

Teacher: Felt good. Was it fun?

Student: Sweaty.

Teacher: It should be sweaty. Do your muscles ache?

Student: A lot.

(Lesson 4)

From the teacher's perspective the purpose of the lesson was fitness and body-building training. However, in the gathering at the end of this lesson, the teacher initiated the discussion with questions about how it felt and whether it was fun. The students responded by saying that it was sweaty and hard work. The teacher then also asks whether weight training to the point of being sweaty was fun. This sequence demonstrates how the teacher instructs the students in a relationship between hard physical work evidenced by being sweaty and pleasure - that is, he provides instruction on the appropriate way to experience this physiological response and what led to it being pleasurable. If this instruction takes hold and the students come to experience hard work as fun, it would be reasonable to expect that the students would choose to seek out further opportunities for pleasure and exert themselves physically in the future. In short, they will have been incited to adopt one of the precepts of a healthy lifestyle - regular vigorous physical activity.

Another example of this relationship - of exerting oneself physically and having fun - occurred in another lesson where the students, Year 6 boys and girls, played floorball (lesson 10). The 
teacher walked around the room saying "keep at it, keep at it, keep at it" fourteen times during the course of the game. During the game one team member displayed extreme irritation and the teacher asked what had happened. The student replied:

Student: It's annoying if you miss and then say something stupid.

Teacher: Take it easy and try to have fun.

Towards the end of the lesson the teachers asked: What do you think? Was it hard work?

The students (a clear majority) responded: It was great fun! (Lesson 10)

What is interesting here is how the teacher in this excerpt sets up an environment in which the students are encouraged to participate vigorously “keep at it, keep at it, keep at it”, but that this should be experienced as fun, even when you miss the ball. The success of the injunction ('to have fun') is evident in the students' final comments. They have (apparently) interpolated themselves into the discourse - hard work is about experiencing pleasure and having fun. To emphasise something as pleasurable directs the pupils as to how they should feel physiological experiences. Emphasising physical activity as pleasurable constructs inclusion and normalisation in so far as it is tied to the right emotions. When physical exertion is portrayed as something that is pleasurable then the resultant feelings of success and happiness encourage individuals to foster the desired state of a good citizen, a physically active healthy citizen. The teachers interpellate students into particular ways of being good students and from those who respond, it appears that they have been very successful. The responding students accept their subjectification, they become students who not only recognise the value of hard work, they enjoy it! Here they are enjoined to constitute themselves as particular subjects; young people who like hard physical activity - who associate sweat with fun. 
To summarise, our analysis of these PE lessons has endeavoured to detect practices of pastoral power within the pedagogical activities of these Swedish PEH teachers. This work revealed three clusters of pastoral governing techniques, togetherness, encouragement and shaping pleasure, and demonstrated how these technologies of power underpin strategies through which students adopt the ethical practices of a healthy self-governance. In these Swedish PE lessons these techniques are employed by teachers to incite young people's assessment and interpretation of themselves, their actions and the feelings they experience when they enact them. Such work facilitates the interpellation of students into particular ways of being good active, healthy citizens. In this manner the students were enjoined to constitute themselves as particular subjects; healthy young people who enjoy vigorous physical activity.

However, at this point the reader might be inspired to question our concerns regarding this state of affairs. At first glance who would consider the atmosphere of togetherness, encouragement and pleasure demonstrated in these PE learning environments as anything other than a reflection of good HPE teaching? Nonetheless, mindful of Foucault's (1994a) warning that the 'point is not that everything is bad, but that everything is dangerous' (p. 256), in the next section we draw on these two case studies to highlight the tensions and contradictions that may result from our professional enthusiasm to embrace caring teaching.

\section{Handle care with care}

In seeking this objective, we want to reiterate two aspects of Foucault's pastoral power modality. Briefly, the mobilization of pastoral power is reliant on pastoral officials or experts creating environments that first provide them with access to each citizen's conscience and subsequently, to shape these consciences according to particular ends (Foucault, 1994a). Our Australian and 
Swedish case studies reveal the range of principles and practices that underpin the HPE/PEH profession's capacity to access the feelings, thoughts and actions of apprentice citizens. Both studies demonstrate the importance of specific learning experiences, such as competitive sport, and the construction of learning environments that reflect togetherness, caring and equality, which the teachers employ to incite even the most recalcitrant of students to experience and adopt the sanctioned practices, attitudes and feelings of healthy living.

Here we have been struck by the pertinence of Rose's (1999) argument that 'through selfinspection, self-problematisation, self-monitoring and confession, we evaluate ourselves according to the criteria provided for us by others' (p.11). The importance of this statement for HPE/PEH lies in the criteria teachers draw upon in their practices of shaping good active, healthy citizens. When HPE/PEH teachers engage in pastoral power practices, the criteria of healthy living they employ reflect specific technologies that have emerged out of medico-scientific research (Gard \& Wright, 2001). In this matter, Ewald (1990) is enlightening when he explains that normalization practices are less a matter of conforming to a standard model than they are to 'reaching an understanding with regard to the choice of a model' (p.148).

Such is the case in contemporary programs of HPE/PEH which privilege a standardized model of healthy living that is 'medicalized and narrowly focused on that which can be easily measured and assessed' (Evans \& Rich, 2009, p. 163). Additionally, researchers have exposed the personal investment many HPE/PEH teachers have in relation to this "model of choice”, demonstrating teachers' uncritical acceptance of health imperatives and the dominance of specific health, physical activity, sport and body discourses in the shaping of HPE/PEH teacher identities (Armour \& Jones, 1998; Macdonald \& Tinning, 1995; Gard \& Wright, 2001; Tinning, 2004; Wright \& Harwood, 2009). 
Yet, despite the number of students who experience the exclusionary practices revealed in the second study, it is within this context of exclusion that the true potency of pastoral power techniques can be found. For the caring pastoral HPE teacher, student exclusion reflects not a call to surrender, but a call to "care more fervently". In supporting this claim we need to consider further the operation of normalization. According to Foucault (1994a), the exercise of governance relies upon the deployment of knowledge as a means of representing reality in forms that can render it governable. For example, the gathering of statistics on states of health serves not only to measure the population's skills and dispositions, but facilitates the creation of discriminating health norms that detect those members of the population who are failing to adopt healthy living practices and in need of intervention. As Ewald (1990) further explains,

The reality of normative equality is that we are all comparable; the norm is most effective in its affirmation of differences, discrepancies, and disparities. The norm is not totalitarian but individualizing; it allows individuals to make claims on the basis of their individuality and permits them to lead their own particular lives. However, despite the strength of various individuals' claims, no one of them can escape the common standard. (p. 154)

Importantly then, the norm is equalizing in that it allows each individual to be compared to all others through a standard of measurement, and from the moment that the norm is established, no one can 'escape its purview' (Ewald, 1990, p.154). Likewise, HPE/PEH students who refuse to abide by the "rules of the game" nonetheless discover what those rules are and what comprises "normal" healthy living despite their own deviance or exclusion. Establishing and reinforcing the norm invites students who do not, for example, find getting sweaty fun and pleasurable, to recognise that getting sweaty and having fun is nonetheless the norm and they need to work upon 
themselves, under the guidance of their teachers and others, to achieve this desired norm. This process reflects Foucault's suggestion that individuals do not impart meaning to discourse, instead it is the 'discursive formation that provides an array of subject positions which individuals may occupy’ (McNay, 1994, p.68). Our analysis provides deeper insight into these operations, providing an 'account for how people are constituted as a result of certain truths being current rather than others' (Hollway, 2001, p. 278), and an understanding of students' investment in the uptake of particular subject positions and the reasons for this investment in terms of power (Hollway, 2001).

Consequently, as HPE/PEH teachers employ the wide range of normalization tools at their disposal to interpellate young people into the arts of healthy active living, they simultaneously detect those students who represent problematic deviations from the norm. As Nadesan (2008) informs, these 'bad or risky subjects are targeted for increased surveillance and disciplinary normalization' (p. 213). Instead of discarding or ignoring problematic students, such deviations call upon the HPE/PEH teacher to care more fervently, to employ more intense and individualized strategies of togetherness, encouragement, familiarity and surveillance. For example, in the Swedish PEH lessons one teacher was literally willing to give a student her shoes to ensure her participation in the activities. An early Australian school inspector effectively captures this sentiment noting that even the laziest of children have within them the 'inclination and power to react to sympathetic and intelligent treatment, if the teacher but find the key' (QDPI, 1930, p. 47, our emphasis). In short, success lies with the 'good' teacher who never abandons her quest for a key to unlock or overcome students’ deviance or resistance.

Notwithstanding this insight, who wouldn’t want their child to have this caring teacher? In his later work, Foucault (1994b) encourages us to attend to those 'strategies by which individuals try 
to direct and control the conduct of others' (p. 298), to understand such strategies in order to enact our 'games of power with as little domination as possible' (ibid). More recently, Nealon (2008) has argued that we should pay attention to those social practices that appear beyond question, as 'power becomes more effective while offering less obvious potential for resistance' (p. 71). As such, our employment of a pastoral power lens in the two case studies of this paper has sought to reveal the manner in which HPE/PEH teaching cloaked in care, disguises the biopedagogical practices of body regulation, normalization, surveillance and intervention (Wright \& Harwood, 2009). Building on this analysis, our final commentary focuses on two implications that motivate our call to handle care with care.

First, in failing to question or disturb the healthy living criteria that lie at the heart of our caring HPE/PEH practices, we as physical educators may intentionally or unintentionally contribute to our students' alienation from their bodies rather than educating them about their bodies (Evans, Davies \& Wright, 2004; Gard \& Wright, 2001). Such a call is not new, as evidenced by a past challenge to the profession:

I want to continue the argument that our traditional practices in physical education construct a body which is objectified and separated from the self; and to argue that we contribute to the notion of the productive body-one which must be worked for instrumental ends (Wright, 2000, p.36).

As Tinning and Glasby (2002) argue, 'even with enlightened curriculum frameworks to guide practice, physical education continues to reproduce values associated with the cult of the body' (p. 111). Consequently, in the absence of a sociocritical appraisal of the factors influencing their health, HPE/PEH students' engagement with the discourses of healthy self-governance leaves 
them vulnerable to a moralizing discourse that positions them as bad, lazy or risky (Gard \& Wright, 2001). Although student's narratives often reveal a complex landscape of young people’s positive sense of agency and resistance (Rich \& Evans, 2009), according to Nadesan (2008), the fear of failure, difference and vulnerability accompanying this work results in 'damaging social-psychic effects as the self is plunged for weaknesses and excesses' (p. 213). Instead of ameliorating this situation, the individualizing techniques of caring teaching may exacerbate students' sense of personal responsibility and the moral obligation they experience, particularly as few would have recourse to the agency that accompanies a refusal of the caring teacher. As Mendus (1993) warns, 'too much emphasis on care may serve to disguise the requirements of justice and equality' (p. 20). To summarize, our caring teaching may foreclose opportunities to explore alternative readings and understandings of healthy bodies and healthy living that better serve our students.

Following on from this, we suggest a second implication resides with the caring, pastoral teacher him or herself. That is, what are the costs to HPE/PEH teachers when we incite them to care? This concern is founded on commentary provided by care ethicists such as Mendus (1993) who states that 'those who present themselves as caring [are] required to carry the entire burden of welfare provision' (p. 20). Findings from our studies reveal the burden of responsibility placed at the feet of $\mathrm{HPE} / \mathrm{PEH}$ teachers who are charged with finding and using the unique keys that can “convert” young people to the active, healthy living agenda. In this manner, teachers of HPE/PEH have been incited to undertake an unrelenting quest to discover, meet and overcome the needs, limited resources, interests or concerns of their students. Although teachers conduct their work within economic, political and cultural constraints, research has shown that many experience guilt, shame and burnout when they fail to meet their perceived responsibilities to 
help students and their family (Chang, 2009). As Walkerdine has long argued, 'nurturant, child centred teaching is an inherently stressful and contradictory attempt to meet the demands of creating a self-regulating individual for the modern state' (quoted in Acker, 1995, p. 31). Consequently, HPE/PEH teachers who believe they have failed in their duty to provide a sufficient "social safety net” (Nadesan, 2008), are likely to experience the self-blame and burnout that accompanies a desire to care about and for, each of their students.

In our efforts to employ a pastoral power lens on HPE/PEH we have sought to reveal the "underbelly" of caring teaching in HPE/PEH. Here we have argued that the danger of caring teaching lies not with our acts of care, of nurturing each member of our "flock", but with the model of healthy living towards which we shepherd them and the burden that the "shepherd" undertakes when he or she conducts this work in HPE/PEH. In providing an initial response to these concerns, we support the argument posed by Gard \& Wright (2001) that 'physical education in schools and universities should be allowed and encouraged to conceive of scientific knowledge about the body [and health] as contested and unstable' (p. 547). Additionally, we argue that HPE/PEH students and their teachers should be provided spaces to critically reflect upon the discourses which have shaped their lives and to challenge the privileging of certain knowledges, practices, bodies and students within HPE/PEH programs. However, a more daring approach might engage with Foucault's (1982) challenge to 'refuse what we are' (p. 785) and to explore the implications of 'a more relaxed and playful approach to physical activity' (Gard \& Wright, 2001, p. 547). We believe these ideas pave the way for future research into the life histories and caring practices of HPE teachers, to explore the models of good healthy living informing their work in order to gain a deeper understanding of the pleasures and costs such work entails. 


\section{References}

Acker, S. (1995) Carry on Caring: The work of women teachers, British Journal of Sociology of Education, 16(1), 21-37.

Annerstedt, Claes (1991). Idrottslärarna och idrottsämnet. Utveckling, mål, kompetens - ett didaktiskt perspektiv. (Göteborg: Göteborg Studies in Education Sciences).

Armour, K.M. \& Jones, R.L. (1998) Physical Education Teachers’ Lives and Careers: PE, Sport and Educational Status. (London: Falmer Press).

Besley, T. (2005) Self denial or self mastery? Foucault's genealogy of the confessional self. British Journal of Guidance and Counselling, 33(3), 365 - 382.

Brown, D. \& Evans, J. (2004) Reproducing Gender? Intergenerational links and the male PE teacher as a cultural conduit in teaching physical education. Journal of teaching in Physical Education, 23, 48-70.

Carr, J. T. (1975). Backing up health education with health education. Report of the Xth ACH-PER National Biennial Conference Held in Perth January $12^{\text {th }}-17^{\text {th }} 210-215$. (Brisbane: ACHPER)

Chang, Mei-Lin. (2009). An Appraisal Perspective of Teacher Burnout: Examining the Emotional Work of Teachers. Educational Psychology Review, 21(3), 193 - 218.

Department of Education Queensland. (1952) Physical Education: Introductory Handbook. (Brisbane: Author). 
Evans, J., Davies, B. \& Wright, J. (Eds.). (2004) Body Knowledge and Control: Studies in the sociology of physical education and health. (London: Routledge.)

Ewald, F. (1990) Norms, Discipline and the Law. Representations Special Issue: Law and the Order of Culture, 30, 131 - 161.

Foucault, M. (1974) Prisons et asiles dans le mécanisme du pouvoir. In edition etablie sous la direction de Daniel Defert et Francois Ewald avec la collaboration de Jacques Lagrange Dits et Ecrits, 1954-1988 / Michel Foucault t. II. (Paris: Gallimard).

Foucault, M. (1977) Discipline and Punish: The birth of the prison. (A. Sheridan, Trans.). (New York: Vintage Books).

Foucault, M. (1982) The Subject and Power. Critical Inquiry, 8(4) 777-795.

Foucault, M. (1990) The Use of Pleasure: The History of Sexuality, Vol. 2. (Robert Hurley, Trans.) (New York: Vintage Books).

Foucault, M. (1994a) Power: The Essential Works of Foucault 1954-1984, Volume III. (J.D. Faubion, Ed., Robert Hurley and others, Trans.) (London: Penguin Books).

Foucault, M. (1994b) Ethics: Subjectivity and Truth: The Essential Works of Foucault 1954-1984, Volume I. (Paul Rabinow, Ed., Robert Hurley and others, Trans.) (London: Penguin Books).

Gard, M. \& Wright, J. (2001) Managing Uncertainty: obesity discourses and physical education in a risk society. Studies in Philosophy and Education. 20(6), 535-549. 
Gore, Jennifer M. (1998). Disciplining bodies: On the Continuity of Power Relations in Pedagogy. In: Popkewitz, T.S \& Brennan, M. (Eds.) Foucault’s Challenge. Discourse, Knowledge, and Power in Education, 231-251 (New York: Teachers College Press).

Great Britain Board of Education. (1933) Syllabus of physical training for schools. (London: H.M.S.O).

Hollway, W. (2001) Gender Difference and the Production of Subjectivity. In M. Wetherell, S. Taylor \& S.J. Yates (Eds.) Discourse Theory and Practice. A Reader, (pp. 272-283). (London: Sage).

Hunter, I. (1994) Rethinking the School: subjectivity, bureaucracy, subjectivity (St Leonards, N.S.W: Allen \& Unwin).

Kirk, D. (1998) The case against the deterioration argument: Lessons from history to inform the future of physical education. The ACHPER Healthy Lifestyle Journal, 45(3), 11-15.

Larsen, A. \& Silverman, S. (2005) Rationales and practices used by caring physical education teachers, Sport, Education and Society, 10(2), 175-193.

Lemke, T. (2000) Foucault, Governmentality, and Critique. [electronic version] Retrieved May 26, 2005 from http://www.thomaslemkeweb.de/publikationen/Foucault,\%20Governmentality,\%20and\%2 0Critique\%20IV-2.pdf.

Macdonald, D. \& Kirk, D. (1996) Private lives, public lives: Surveillance, identity and self in the work of beginning physical education teachers. Sport, Education and Society, 1(1), 59-75. 
Macdonald, D. \& Tinning, R. (1995) PETE and the trend to proletarianization: a case study. Journal of Teaching in Physical Education, 15(1), 98-118.

McCuaig, L. (2008) Teaching the art of health living: a genealogical study of H-PE and the moral governance of apprentice citizens. Unpublished doctoral thesis, The University of Queensland, Brisbane, Australia.

McCuaig, L. \& Tinning, R. (2010) HPE and the moral governance of pleasurable bodies. Sport, Education and Society, 12(3), 277 - 294.

McCuaig, L. (2011) Dangerous carers: Pastoral power and the caring teacher of contemporary Australian schooling. Educational Philosophy and Theory, Early View: 1-16.

McNay, L. (1994) Foucault: A Critical Introduction (Cambridge: Polity Press).

Mendus, S. (1993) Different Voices, Still Lives: Problems in the Ethics of Care, Journal of Applied Philosophy, 10 (1), 17-27.

Meredyth, D. \& Tyler, D. (Eds.). (1993) Child and Citizen: genealogies of schooling and subjectivity (Brisbane: Griffith University).

Nadesan, Maija Holmer. (2008) Governmentality, Biopower and Everyday Life. (New York: Routledge).

Nealon, J. (2008) Foucault beyond Foucault: power and its intensifications since 1984 (Stanford, California: Stanford University Press).

Noddings, N. (1984) Caring: A feminine approach to ethics and moral education (Berkley: University of California Press). 
Noddings, N. (1992) The Challenge to Care in Schools: An Alternative approach to Education (New York: Teachers College Press).

The National Swedish Agency for Education (2000a) Det livslånga livsvida lärandet. Stockholm: Liber.

The National Swedish Agency for Education (2000b) Grundskolan. Kursplaner och betygskriterier - Idrott och hälsa. Stockholm: Fritzes.

Öhman, M. (2010) Analysing the Direction of Socialisation from a Power Perspective. Sport, Education \& Society, 15(4), 393-409.

Owens, L. \& Ennis, C. (2005) The Ethic of Care in Teaching: An Overview of Supportive Literature, Quest, 57(4), 392-425.

Queensland Department of Public Instruction. (1930) Annual Report. (Brisbane: Government Printer).

Queensland Department of Public Instruction. (1952) Annual Report. (Brisbane: Government Printer).

Queensland School Curriculum Council, (1999a) Health and Physical Education, Years 1-10 Syllabus. (Brisbane: Publication Services, Education Queensland).

Queensland School Curriculum Council, (1999b) Health and Physical Education: Sourcebook. (Brisbane: Publication Services, Education Queensland).

Queensland School Curriculum Council, (1999c) Health and Physical Education: Initial Inservice. (Brisbane: Publication Services, Education Queensland). 
Quennerstedt, M., Burrows, L. \& Maivorsdotter, N. (2010) From teaching young people to be healthy to learning health. Utbildning \& Demokrati: Tidskrift för didaktik och utbildningspolitik, 19(2), 97-112.

Rich, E. \& Evans, J. (2009). Performative health in schools: welfare policy, neoliberalism and social regulation? In Wright, J. \& V. Harwood. (Eds). Biopolitics and the 'obesity epidemic': governing bodies (pp. 157 - 171). (New York: Routledge).

Rose, N. (1998) Inventing our Selves. Psychology, Power and Personhood (Cambridge, Cambridge University Press).

Rose, N. (1999) Powers of Freedom: reframing political thought. (Cambridge: Cambridge University Press).

Rose, N. (2000) Identity, genealogy, history. In Paul Du Gay, Jessica Evans \& Peter Redman (Eds.), Identity: a reader (pp. 313-326). (London: Sage Publications in association with The Open University).

Rose, N. (2001). The Politics of Life Itself. Theory, Culture and Society, 18(6), 1-30.

Rossi, T., Tinning, R., McCuaig, L., Sirna, K. and Hunter, L. (2009). With the best of intentions: A Critical Discourse Analysis of physical education curriculum materials. Journal of Teaching in Physical Education, 28 1: 75 - 89.

Rovegno, I. \& Kirk, D. (1995) Articulations and silences in socially critical work on Physical Education: Toward a Broader Agenda, Quest, 47, 447-474.

State Official Report. (2000) Demokratiutredningens betänkande. En uthållig demokrati! Politik för folkstyrelse på 2000 - talet. 
State Official Report. (2008). Lärarutbildningsutredningen: Sustainable teacher education.

Tinning, R. (2004) Rethinking the preparation of HPE teachers: ruminations on knowledge, identity, and ways of thinking, Asia-Pacific Journal of Teacher Education, 32(3), 241-253.

Tinning, R. \& Glasby, T. (2002) Pedagogical work and the 'cult of the body': Considering the role of H-PE in the context of the 'new public health'. Sport, Education \& Society, 7(2), 109119.

Wright, J. (1997) The construction of gendered contexts in single sex and coeducational physical education lessons, Sport, Education and Society, 2(1), 55-72.

Wright, J. (2000) Bodies, meanings and movement: A comparison of the language of a physical education lesson and a Feldenkrais movement class. Sport, Education and Society, 5(1), 35-49.

Wright, J. \& Harwood, V. (Eds.). (2009) Biopolitics and the 'obesity epidemic': governing bodies. (New York: Routledge). 